This is an electronic reprint of the original article. This reprint may differ from the original in pagination and typographic detail.

Author(s): Backman, Jussi

Title: Being Itself and the Being of Beings : Reading Aristotle's Critique of Parmenides (Physics 1.3) after Metaphysics

Year: $\quad 2018$

Version:

Please cite the original version:

Backman, J. (2018). Being Itself and the Being of Beings : Reading Aristotle's Critique of Parmenides (Physics 1.3) after Metaphysics. Epoché: A Journal for the History of Philosophy, 22(2), 271-291. https://doi.org/10.5840/epoche20171220103

All material supplied via JYX is protected by copyright and other intellectual property rights, and duplication or sale of all or part of any of the repository collections is not permitted, except that material may be duplicated by you for your research use or educational purposes in electronic or print form. You must obtain permission for any other use. Electronic or print copies may not be offered, whether for sale or otherwise to anyone who is not an authorised user. 
This is the accepted manuscript version of the following article:

Jussi Backman, "Being Itself and the Being of Beings: Reading Atistotle's Critique of Parmenides (Physics 1.3) after Metaphysics," Epoché: A Journal for the History of Philosophy 22:2 (2018): 271-91, available in final form at https://doi.org/10.5840/epoche20171220103.

\title{
Being Itself and the Being of Beings:
}

\section{Reading Aristotle's Critique of Parmenides (Physics 1.3) after Metaphysics ${ }^{1}$}

\author{
JUSSI BACKMAN
}

University of Jyväskylä

\section{Abstract}

The essay studies Aristotle's critique of Parmenides (Physics 1.3) in the light of the Heideggerian account of Platonic-Aristotelian metaphysics as an approach to being (Sein) in terms of beings (das Seiende). Aristotle's critique focuses on the presuppositions of the Parmenidean thesis of the unity of being. It is argued that a close study of the presuppositions of Aristotle's own critique reveals an important difference between the Aristotelian metaphysical framework and the Parmenidean "protometaphysical" approach. The Parmenides fragments indicate being as such in the sense of the pure, undifferentiated

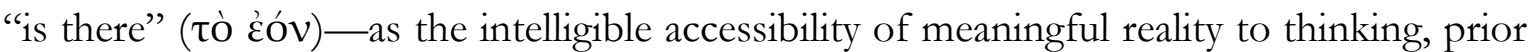
to its articulation into determinate beings. For Aristotle, by contrast, "being itself" ( $\alpha$ ủtò

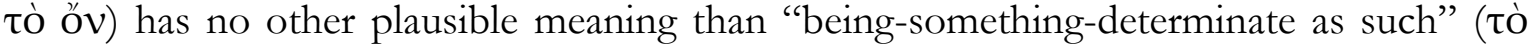
ö $\pi \varepsilon \varrho ~ o ̋ v \tau \iota)$, which itself remains equivocal. In this sense, Aristotle can indeed be said to conceive being in terms of beings, as the being-ness of determinate beings. 


\section{PRESOCRATIC PROTOMETAPHYSICS}

The term "Presocratic" is in itself evidence of our ingrained tendency to read the earliest Greek philosophers in the light of Socrates-Plato. Our embeddedness in the tradition famously described by Alfred North Whitehead as a "series of footnotes to Plato" makes us in many ways philosophically much closer to Plato and Aristotle than to Parmenides and Heraclitus, who preceded them only by a century. ${ }^{2}$ The Platonic model, according to which a philosophical account of the fundamental structure of reality is to be articulated with a reference to the ideal and universal determinations granting identity, permanence, and determinate structure to particular spatiotemporal beings, grew into one of the most deeply entrenched postulates of Western thought.

In the later Heidegger's formulation, one principal way of characterizing this Platonic heritage - which, for Heidegger, coincides with Western metaphysics as such —is as an approach to being (Sein) as such in terms of beings (das Seiende). ${ }^{3}$ Platonic metaphysics is focused on the "being of beings" (Sein des Seienden) in the sense of the "being-ness" (Seiend-heit) common to everything that is - in other words, on the maximally universal structures of all determinate and articulate instances of "to be." This core topic is conveyed by the Greek oúoí $\alpha$, which first becomes a philosophical watchword with Plato (Phaedo 78d1-7; Republic 7.534a2-4). ${ }^{4}$ In his earlier work, Heidegger tirelessly underlines the phenomenological implications of this metaphysical key term: the fact that one of the primary meanings of oúrí $\alpha$-an abstract noun derived from the present participle of the verb "to be" and thus literally translatable as "beingness"- in prephilosophical parlance is "property" or "estate" points to an implicit understanding of being as that which is accessible, at hand, in a word, present. ${ }^{5}$ According to

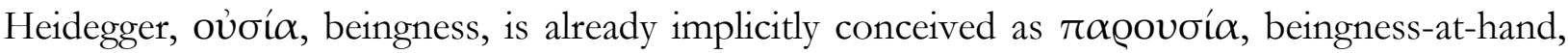
as presence in the sense of accessibility and availability. Accordingly, the metaphysical focus on the being(ness) of beings is inherently a focus on that by virtue of which determinate beings are accessible qua more or less stable, self-identical, and determinate_-their "substantial," constant presence (beständige Anwesenheit). ${ }^{6}$

In Aristotle's categorical ontology, modelled on the subject-predicate syntax of predicative assertions, oúcí $\alpha$ gains the specific sense of the "substantial" mode of being of those entities 


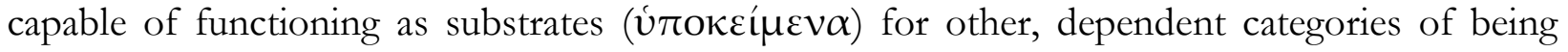
such as qualities, quantities, and relations (Categories 5.2a11-19). ${ }^{7}$ As Heidegger puts it in his Contributions to Philosophy (1936-38), the Aristotelian "leading question" (Leitfrage) of metaphysics

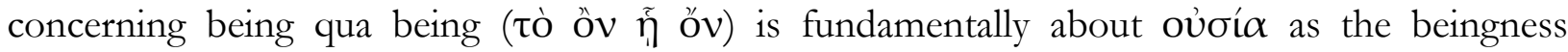
(Seiendheit) of beings. ${ }^{8}$

Here being [ $\mathrm{Sein}]$ means beingness. Expressed at once therein is this: despite the denial of its generic character [by Aristotle], being (as beingness) is always and only meant as . . . the common and thus what is common to every being. ... The answer to the leading question is the being of beings [Sein des Seienden], the determination [Bestimmung] of beingness (that is, the providing of the "categories" for oú $\sigma i \alpha) .{ }^{9}$

In the 1941 essay "Metaphysics as History of Being," we find a similar characterization: here, Heidegger notes that Plato's and Aristotle's approaches to oúoí $\alpha$ both give an account, "from the vantage point of beings [das Seiende] relative back to beings," of what beings are and that they are. 'Within its history as 'metaphysics,' the truth (disclosure) of being [Sein] is limited to beingness [Seiendheit]."10

The emergence of the Platonic metaphysics of oủoí $\alpha$ signifies, for Heidegger, a "first end" or a "first completion" of the Presocratic "first inception" (der erste Anfang) of philosophy manifested in the thinking of Anaximander, Parmenides, and Heraclitus. ${ }^{11}$ This completion can be understood in a double sense. On the one hand, as is suggested by Plato's fascination with Parmenides_-most evident in the dialogue bearing the latter's name-the Platonic beginning explicitly understood itself as a reappropriation of the quest for the unity of being inherent in the Presocratic inception. To this extent, as Heidegger puts it, it is indeed appropriate to characterize pre-Platonic philosophy as "pre-metaphysical” (vor-metaphysisch). Presocratic thinking is the inception (Anfang), the historical origin and source, of metaphysics in the sense that it introduces a new focus on being (Sein) as such as pure accessibility, as pure "abiding-inpresence" (Anwesung), conceived as the "genealogical" origin or provenance (Herkunft) of all determinate instances of meaningful presence and thus itself "maximally present" (Anwesendste) 
and "maximally being" (Seiendste). This paves the way for the Platonic notion of the Idea as that which is "most beingful" (öv $\tau \omega \varsigma$ öv). On the other hand, contrary to the Platonic model, which constitutes the true chronological beginning (Beginn) of metaphysics proper, Presocratic thought does not yet conceive being as the universal feature common (אotvóv) to particular, determinate beings, in other words, as a being(ness) abstracted from beings. ${ }^{12}$

From this perspective, the Presocratic/pre-Platonic inception shows itself as a "protometaphysical" preparation for metaphysics proper, that is, for the Platonic designation of a determinate conceptual form as the unifying "one above many" and for the dialectical approach to the Idea of the Good, the supreme Idea, as the unifying point of reference for all other Ideas. These are profound transformations of the Presocratic search for a unity of being not over and above its particular instances but prior to the conceptual differentiation of meaningful presence by means of determinate notions, typically regarded by the Presocratics as organized into basic binary pairs of conceptual opposites (such as light/dark, hot/cold, and male/female). ${ }^{13}$

Like Plato, Aristotle saw a critical reappropriation of the Presocratics - an appreciation of the profundity of their insights as well as their conceptual shortcomings — as a prerequisite for his own intellectual undertaking. In the Physics and related treatises, his main historical concern is to show why his predecessors - the Eleatic school of Parmenides, in particular-failed to produce an adequate philosophical account of the phenomena of becoming, change, and

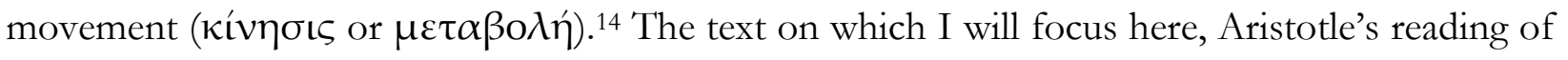
Parmenides in the first book of the Physics, is arguably one of the finest ancient examples of philosophical critique in the literal sense of the Greek K@íveıv: an analysis, differentiation, and delimitation of the inherent presuppositions of a thinker's conceptual framework with the aim of revealing the limitations of its scope and elaboration.

In what follows, a similar exposition of the premises of the Aristotelian critique will be attempted. I will argue that these premises are inherently Platonic and "metaphysical" in the Heideggerian sense. Two main points will be maintained:

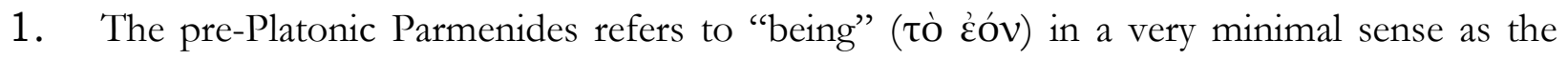
"there is" or the "is there," that is, as the sheer thereness or presence of reality insofar as it 
is accessible to thinking. Parmenidean being is undifferentiated intelligibility as such, prior to its conceptual or discursive articulation into determinate intelligible entities. As such, it is simple and absolute and therefore one and unique.

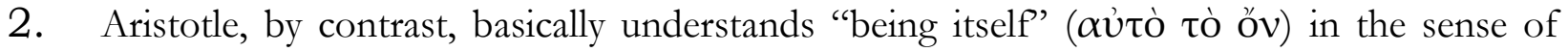
being-a-determinate-something, that is, of being something that can be discursively determined by the various categorial forms of predication and is thus capable of being designated by either the subject or the predicate of a declarative assertion. In other words, Aristotle thinks being as the beingness of beings. From this vantage point, the Parmenidean undifferentiated and prediscursive unity of being loses its plausibility.

I will not focus here on Heidegger's extensive and multifaceted readings of Parmenides or Aristotle, which also include some remarks on Aristotle's critique of the Eleatics. ${ }^{15}$ As several scholars have pointed out, from a Heideggerian perspective, Aristotle's attempt to conceptualize the temporal dimensionality of movement and becoming can also be seen as a kinetic radicalization of ontology with regard to the static and presential being of Parmenides. ${ }^{16}$ Even though, from the very outset, the Heideggerian philosophical project seeks to rethink certain foundational principles of the metaphysical legacy of Aristotelianism, in his early work Heidegger tends to read Aristotle against Aristotle, reappropriating the radical potential inherent

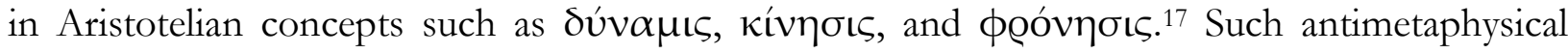
rereadings of Aristotle have since become common in Heidegger-inspired studies. ${ }^{18}$ Without challenging the legitimacy of this approach, I argue that Aristotle criticizes Parmenides on the basis of certain ontological assumptions regarding the meaning of "being itself" - not shared by Parmenides— that can indeed be identified as metaphysical in the later Heidegger's sense.

\section{Parmenides: The UndifFerentiated Unity of BeING}

Aristotle, like Plato, considers Parmenides's decisive philosophical contribution to be his thesis of the unity of being. Before turning to Aristotle's critique, let us briefly outline how this thesis is established in Parmenides's Poem. 
The fragments of Parmenides's Poem famously recount the narrator-thinker's journey to a divine domain beyond the "roads of Night and Day," that is, beyond the most elementary binary oppositions of everyday reality (DK 28 B 1.1-21). ${ }^{19}$ This journey culminates in the narrator's encounter with a nameless goddess who promises to indicate to him the absolute truth $(\dot{\alpha} \lambda \eta \dot{\eta} \theta \varepsilon\llcorner\alpha)$ about all things - the most fundamental and certain level of intelligible evidence (B 1.22-32). ${ }^{20}$ In addition to understanding this level, the goddess assigns to the thinker the task of grasping the way in which the "impressions" or "acceptances" ( $\delta$ ó $\xi \alpha \mathrm{l})$ of "mortals"— that is, the ordinary level of everyday human experience-ultimately arise and gain their relative legitimacy from the fundamental level. ${ }^{21}$ The "phenomenological" reading introduced by Karl Reinhardt and developed by scholars such as Hans Schwabl has shown that rather than dismissing the mortal $\delta o ́ \xi \alpha \mathrm{\iota}$ as a contingent error or illusion, Parmenides's Poem can be interpreted as emphasizing their reality and necessity as the indispensable structure of being as it shows itself in everyday experience. ${ }^{22}$ The thinker's task is that of understanding

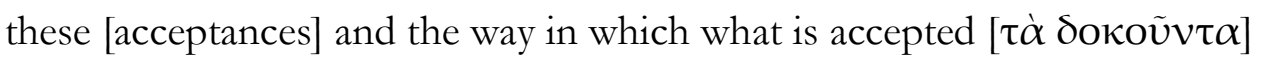

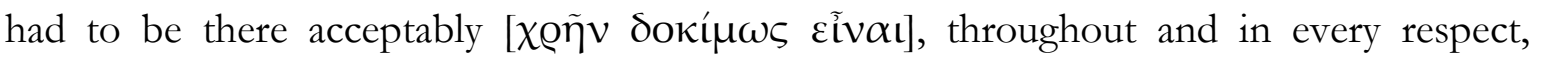

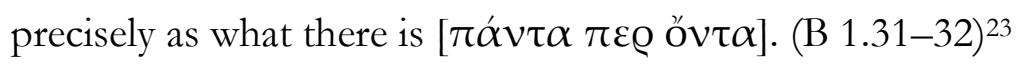

Moreover, what is generally assumed to be the ending of the $\Delta$ ó $\xi \alpha \iota$ part of the Poem states: "In

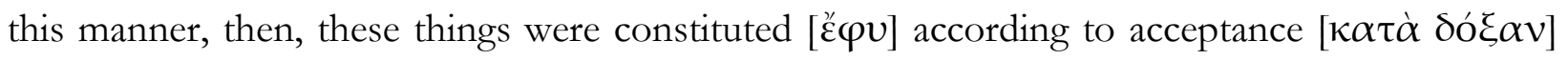
and are there even now." (B 19.1) Things as they are constituted from the perspective of the mortal acceptances "are there even now," without any further qualification.

The distinction between $\dot{\alpha} \lambda \eta \dot{\theta} \theta \varepsilon\llcorner\alpha$ and the $\delta o ́ \xi \alpha \mathrm{L}$ is rooted in the insight that while, in the context of everyday experience, some things are "accepted" as being there and others as not being there, anything that can be meaningfully intended in thought or speech must be in some way constantly accessible to the thought that intends it. In order to grasp the absence of coffee from my empty cup, I must be able to intend the absent coffee as absent; in other words, coffee must be present to my intending thought as absent. From the point of view of pure thought in the sense of simple awareness (vóos, vocĩv), of the intuitive intending of things, everything is thus 
uniformly accessible and present, that is, intelligible. There is nothing absolutely absent and inaccessible, since this would be equivalent to complete unintelligibility.

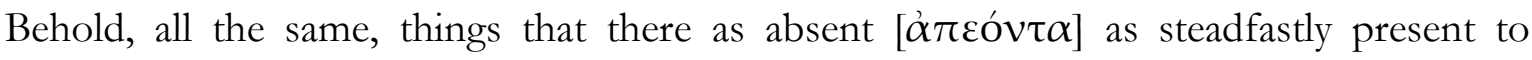
awareness [vów $\pi \alpha \varrho \varepsilon o ́ v \tau \alpha]$;

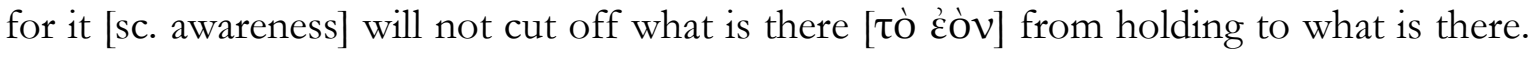
(B 4.1-2) 24

Being as pure intelligibility and awareness as pure receptivity to intelligibility are thus two

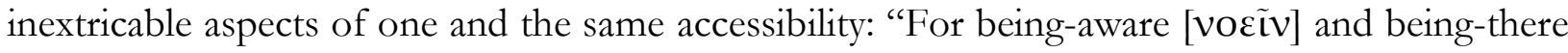
[عĩval] are one and the same." (B 3) This does not suggest, as it might for a post-Cartesian thinker, that being is understood as a mere correlate of the thinking activity of self-conscious subjectivity. ${ }^{25}$ Rather, the emphasis is on showing how thinking is possible only as receptivity to being, as an intending of being correlated with being.

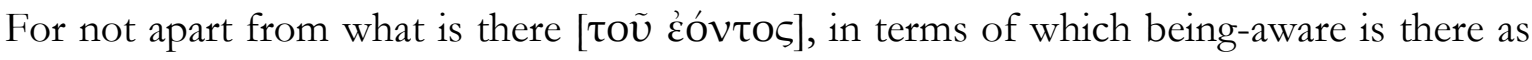
expressed,

will you discover being-aware [Voeĩv]. (B 8.35-36)

What is inaccessible to thinking must therefore be absolutely excluded from the sphere of intelligibility (B 2.7-8, 7.1-2). It follows that being/intelligibility as such must be completely and perfectly self-identical, self-sufficient, and unitary, safeguarded from any interaction with and from any reference to a nonintelligible outside or other of intelligible being-there. This is the core insight of Parmenides' way of $\alpha \lambda \eta \dot{\theta} \varepsilon\llcorner\alpha$, of intelligible evidence, which is also the way of

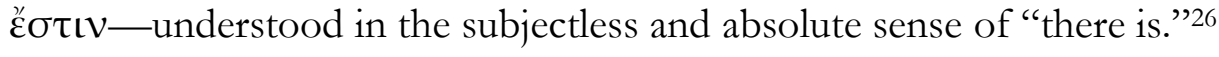

Only a single account of a way

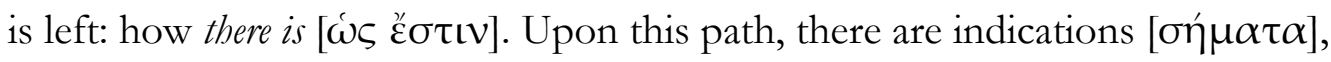


a good many of them: how what is there is there without becoming and also without passing-away,

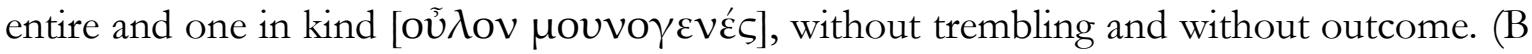
$8.1-4)^{27}$

Accordingly, the goddess's remarks on the specific temporality of being can be taken not as an assertion of the timeless eternity or the everlasting duration of what is, but rather as an indication that to being/intelligibility as such, only the present tense applies. Spatial and temporal absence ("is not here," "is not anymore," "is not yet") are only modifications of pure presence. In order for thinking to be able to attribute relative absence to a particular thing, that thing must in fact be present to the thinking that intends it and refers to it as absent for the moment.

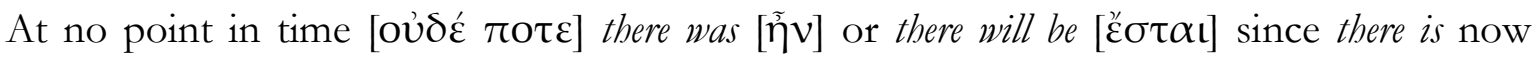

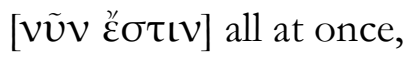
unitarily-uniquely [ع̈v], constantly. (B 8.5-6)

As Charles H. Kahn suggests, Parmenides is clearly drawing on the durative aspect of the Greek verb عĩval, "to be," which lacks the nondurative aorist and perfective aspects. ${ }^{28}$ Being never takes place at a specific point in time $(\pi \mathrm{O} \tau \varepsilon)$ and is never something already completed; at any given time, being is something that is presently going on, a process that can be expressed exclusively using the present tense. There is no point in time at which being would be a thing of the past or something yet to come. ${ }^{29}$ If anything at all can be said about being or presence as

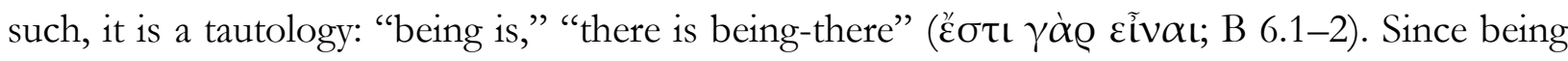
as such precedes all meaningful articulations and differentiations and contains them within itself, it cannot in itself be further articulated or differentiated. Intelligibility, meaningful accessibility, is a single, homogeneous, and undifferentiated whole.

Contrary to another established tradition of reading Parmenides, this does not mean that time, absence, change, becoming, multiplicity, and difference are mere illusion. They can be 
taken simply as a derivative and dependent level of being: none of the above determinations apply to being/intelligibility as such, since they are all meaningful only within the sphere of being/intelligibility. Determinate and nameable beings are only in a derivative sense as the particular aspects through which the everyday discursive thinking of the "mortals" articulates reality. The names that designate and differentiate them in discourse ultimately refer to beingthere as such, with reference to which all the things the mortals ordinarily accept as true/evident $(\dot{\alpha} \lambda \eta \theta \tilde{\eta})$ are named (ỏvó $\mu \alpha \sigma \tau \alpha$ เ; B 8.36-41, cf. 8.53, 9.1, 19.3)..$^{30}$ All the names for beings are basically names for being as such.

This reading gives us all the more reason to take seriously Heidegger's emphasis on the

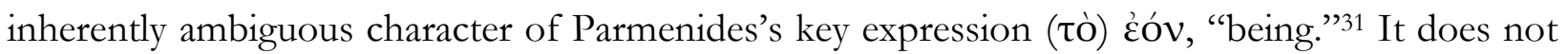
simply designate, in a nominal sense, "that-which-is"; it is essentially a participial form in the literal sense that it names beings to the extent that they "participate" in the process of beingthere. (Tò) દ̇óv names the very "is-ness" of what is. Thus, taking into account Kahn's remarks on the locative sense ("is present," "is on hand," "is effectively (there)") as a basic meaning of

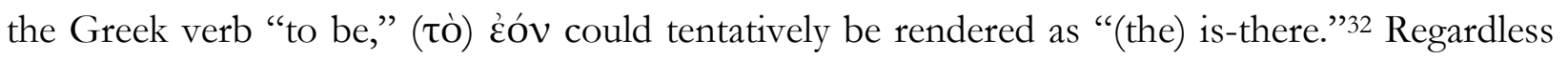
of which specific things happen to be there or not there at any specific time, "an is-there is

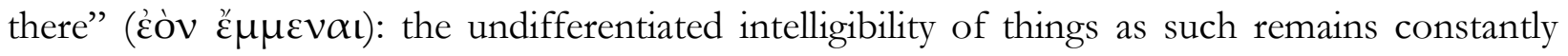
present.

This is the cornerstone of the Parmenidean thesis of the unity of being. Being is pure intelligibility, and its other is pure nonbeing/nonintelligibility that remains absolutely irrelevant for philosophical thought. From this, Parmenides' Eleatic disciples, Zeno and Melissus, apparently draw the further conclusion that it is the task of philosophy to show becoming, plurality, relativity, and difference to be mere epiphenomena that are encountered only from a partial and finite perspective. The gist of Zeno's famous paradoxes, as paraphrased by Aristotle (Physics 6.9), is to show that any attempt to think change and multiplicity rigorously is at once at odds with itself. 


\section{ARISTOTLE'S CRITIQUe of PARMENIDEAN UNITY}

In Aristotle's eyes, the Eleatics' fundamentally absurd denial of change and multiplicity is motivated precisely by their exclusion of nonbeing from being-by the assertion of the absolute identity of being with itself and its disjunction from any relations to anything other than being.

The first ones to inquire philosophically into truth and into the nature of beings [ $\varphi v ́ \sigma \mathrm{v}$ $\tau \tilde{\omega} \nu$ óv $\tau \omega \nu]$ wandered astray in their inquiry, as if their lack of experience had thrust them upon some other path. They maintain that no being comes to be or passes away,

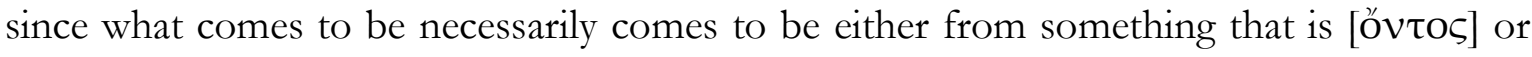

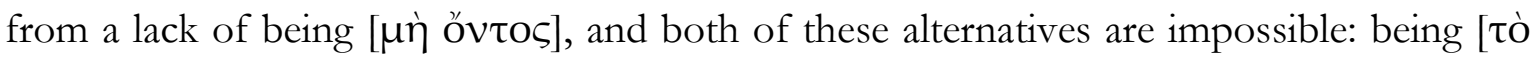
öv] does not come to be, since it already is, and nothing comes to be from a lack of being,

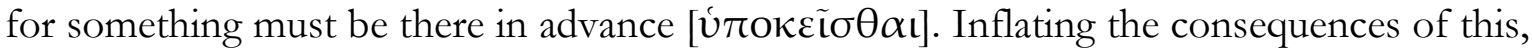

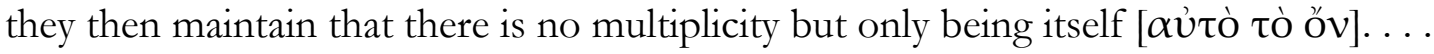

For these reasons the earlier thinkers wandered so far astray from the path that leads to coming-to-be and passing-away and all transition $[\mu \varepsilon \tau \alpha \beta o \lambda \eta v v]$ in general. Had but

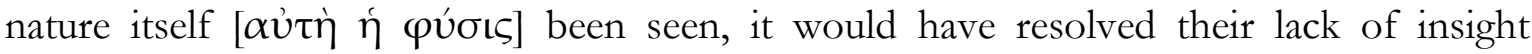

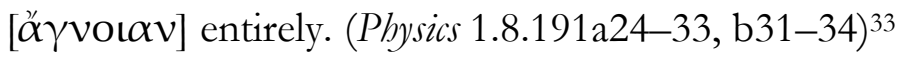

Lines 191b33-34 have been transmitted in the manuscripts and commentaries with a

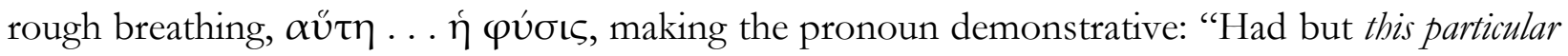
nature been seen." 34 However, the passage becomes even more natural when read with a

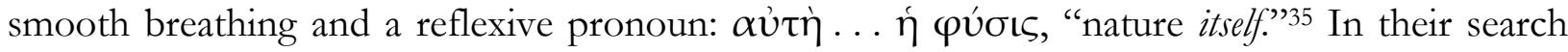

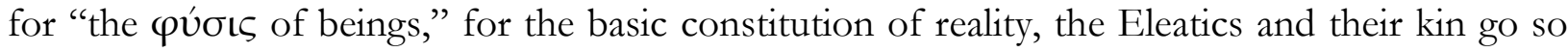

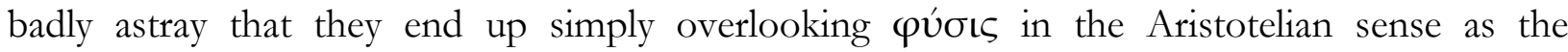
spatiotemporal realm of materiality and becoming. They are unable to distinguish between two different domains: (1) that of physics, that is, the material and sensible reality subject to change, and (2) that of metaphysics or first philosophy in the narrow sense of theology, that is, the 
ontologically perfect and supreme type of entity (cf. Metaphysics 6.1.1026a23-32, 12.1.1069a18b2). Rather, the Eleatics conceive the former in terms of the latter. They recognizelegitimately, for Aristotle-that there must ultimately be an absolutely simple and immutable kind of being, but owing to their refusal to make any distinctions within the sphere of being, they illegitimately apply this insight to all beings. In insisting that simplicity and immutability pertain even to sensible-material reality, the Eleatics deny the very possibility of a philosophical grasp of movement and change as such (Physics 1.2.184b25-185a5). In other words, their approach is that of a nonphysical, metaphysical "physics."

Even if in other respects the discourse of those following Parmenides and Melissus is quite appropriate, it surely cannot be considered physical [ $\varphi v \sigma \iota \kappa \tilde{\omega} \varsigma]$ discourse. That there are some ungenerated and completely immutable beings belongs to the realm of another, more fundamental study, rather than that of physics. They presupposed that there is

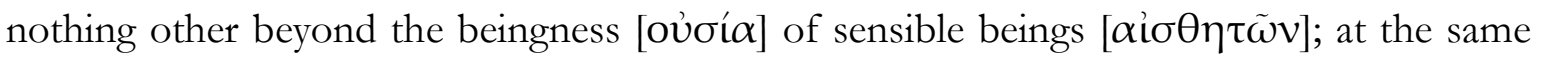

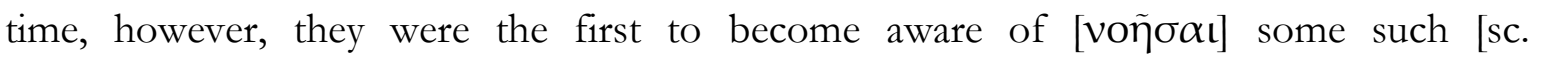
ungenerated and immutable] realities [ $\varphi \hat{v} \sigma \varepsilon \iota \varsigma]$ as preconditions for any knowledge

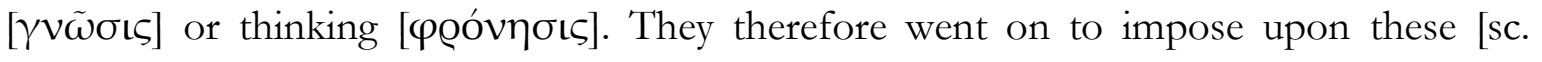
sensible things] discourses based on the other [sc. ideal, supersensible] realm. (De caelo 3.1.298b17-24)

Aristotle is careful, however, to distinguish between the disciples of Parmenides-Zeno and, in particular, Melissus, whose alleged thesis of a material ( $\kappa \alpha \tau \dot{\alpha} \tau \dot{\eta} v \tilde{v} \lambda \eta v)$ unity of being he dismisses as being "rather crude" - and Parmenides himself, who "seems to be somewhat more perceptive $[\mu \tilde{\alpha} \lambda \lambda$ ov $\beta \lambda \varepsilon \dot{\varepsilon} \tau \omega \nu]$ in his discourse" in restricting the thesis of unity to a

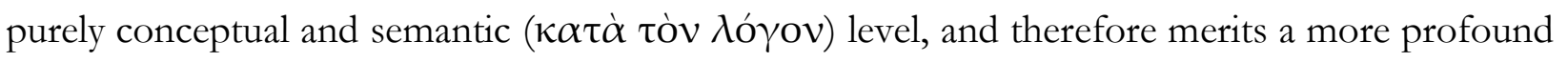
analysis than the patently absurd conclusions of the other Eleatics (Metaphysics 1.5.986b18-20, 26-28). Aristotle agrees with other ancient authors that in the second part of his Poem on the $\delta o ́ \xi \alpha \mathrm{L}$, Parmenides does allow for multiplicity and difference in the realm of the senses, and 
thus himself produces a kind of epiphenomenal "physics" that fixes binary oppositions as the basic structure of sensible nature.

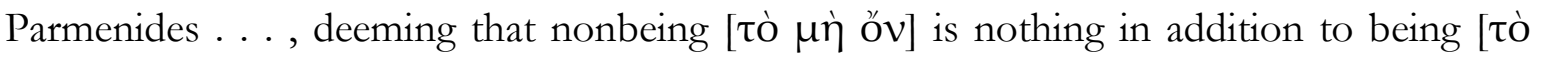
óv], thinks that there is, by necessity, a unity [ع́v]—being-and nothing else...

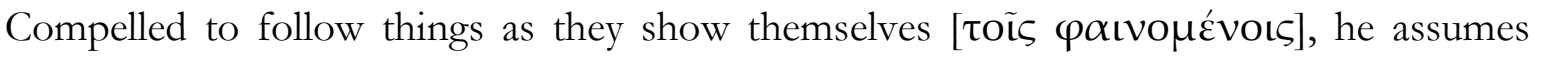

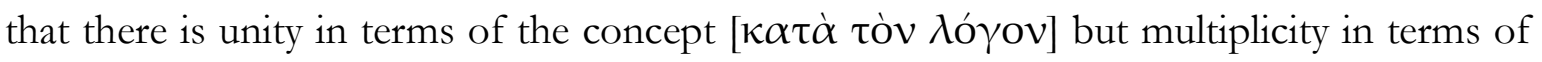

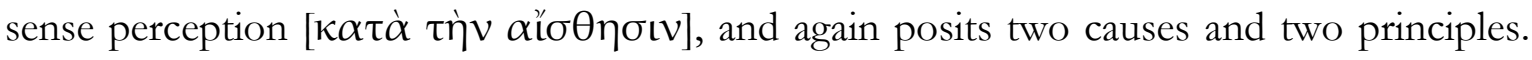
(986b27-34)

On this reading, Parmenides would assert the priority of the ultimate conceptual unity of beings in terms of their being over the concrete sensory evidence of their multiplicity (cf. De generatione et corruptione 1.8.325a2-23). In other words, while not denying the possibility of a

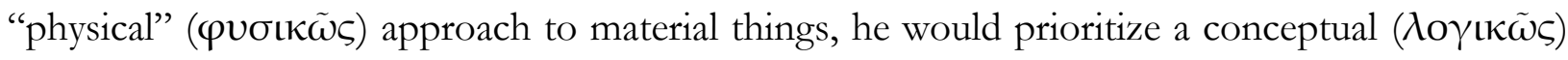
approach to being (cf. Physics 3.5.204b4-22; De generatione et corruptione 1.2.316a6-14). Parmenides's thesis would be not that there is only one thing but that the meaning of being is identical for all beings, namely, intelligible accessibility.

Aristotle thus discovers two key presuppositions behind the Parmenidean thesis of unity: (a) that "being" is a univocal term and (b) that being alone is and nonbeing ( Both receive a systematic discussion in Physics 1. As we will see, the former presupposition is refuted by Aristotle; the latter is qualified by him in important ways.

\section{a) The Univocity of Being Refuted}

As construed by Aristotle, there are two main faults in Parmenides's reasoning that being is one for all beings: a false ( $\psi \varepsilon v \delta \tilde{\eta} \varsigma)$ presupposition and an invalid inference in which the conclusion does not follow from the premises (Physics 1.3.186a23-24). First of all, Aristotle maintains, Parmenides's underlying presupposition that "being" has a single meaning is inadequate. It is a central undertaking of Aristotle's Metaphysics to show that "to be" has different meanings in different contexts_-such as substantial/accidental being and actual/potential being-that 
cannot be referred back to any simple comprehensive unity. Being is not a univocal and definable genus that would comprehend everything that is; in fact, such a genus is impossible (Metaphysics 3.3.998b22-27; 5.7.1017a7-b9; 6.2.1026a33-b2). With regard to Parmenides, Aristotle pursues a reductio ad absurdum of the alleged hypothesis that being ( $\tau$ ò ôv) is articulated in a simple and absolute sense ( $\alpha \pi \lambda \tilde{\omega} \varsigma \ldots \lambda \dot{\varepsilon} \gamma \varepsilon \sigma \theta \alpha \mathrm{s}$; Physics 1.3.186a24-25).

Aristotle starts by demonstrating that even if we grant, for argument's sake, that "being" has a univocal meaning (in either of two conceivable senses of this thesis), the conclusion that being is one, whether this is taken to mean the material or the conceptual unity of all beings, does not follow. ${ }^{36}$ Aristotle first shows, using "being white" as an analogous example, that this is the case if "being" is understood as a universally applicable predicate.

His conclusion does not follow, for

[1.] if we consider white things exclusively and

[2.] "white" has a single meaning,

[3.] white things are nonetheless a multiplicity, not a unity.

That which is white would not be a unity either in terms of [material] continuity or conceptually [ $\left.\tau \tilde{\omega} \lambda{ }^{\prime} \gamma \omega\right]$, since "to be white" would not be the same as "to be something that has assumed whiteness." Even so, there would be nothing separate beyond that which is white, since whiteness and the thing in which it is present are not different in the sense of being separate, but in terms of their "to be."

But Parmenides did not yet see this matter as a whole. (186a25-32)

The point of the analogy is that having one and the same attribute (whiteness) does not make things materially or conceptually one, given that their substantial being ("to be something") remains distinct from their qualified being ("to be something white"). Even if there were only white things, it would not follow that there would be only one thing, identical with whiteness itself, or that all things would be merely particular instances of whiteness and nothing other. By analogy, if we suppose that the predicate "is a being" applies to everything, it does not follow that there is only one being, identical with "being itself," or that there are only particular instances of one and the same beingness. 
Moreover, this very construal of the univocity of being is untenable. Like Kant, Aristotle argues that being as such-unlike whiteness - is not a "real predicate" of entities: predicating "being" of something does not assign any new property to that thing and tells us nothing about the specific features of the particular thing in question. ${ }^{37}$ If "being" were merely an attribute of all things, we would have to make an absurd distinction between "to be something" and "to be something that is," which Parmenides could not accept without giving up the univocity of being.

Thus, [if one follows Parmenides,] one has to suppose not only

[1.] that "being" has a single meaning, whatever it is predicated of, but also

[2.] that it signifies something that as such is [ö $\pi \varepsilon Q$ ǒv] and as such is one [ö $\pi \varepsilon Q ~ \varepsilon ́ v]$.

[a.] A coincidental attribute $[\sigma v \mu \beta \varepsilon \beta \eta \kappa o ́ s]$ is articulated only in terms of an

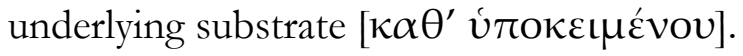

[b.] Thus: the thing of which being is a coincidental attribute would not be, since it would be something other than being, and in that case, there would be something that is not.

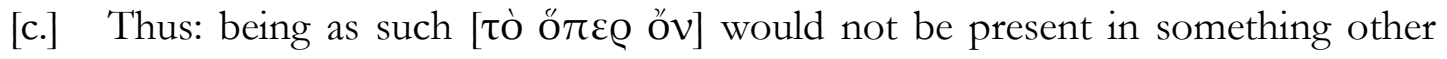
than itself, since this other could not be something that is,

[d.] unless being has many meanings, each of which would signify a determinate mode of being.

But it is presupposed [by Parmenides] that being has a single meaning.

(186a32-b4)

Rather than a universal predicate of all things, univocal being would thus have to mean thinghood as such, that is, the substantial being of entities to which attributes can be attached. But, Aristotle goes on to show, even on this interpretation of the alleged univocal meaning of being, Parmenides's thesis of the unity of being does not follow. If the single meaning of being is construed as the substantial being of things, it follows that "being-white," or any other kind of merely attributable being-such-and-such, is not a mode of being. This is manifestly absurd; " $x$ is 
white" obviously tells us something about what this particular $x$ is like and is thus one way of determining its being.

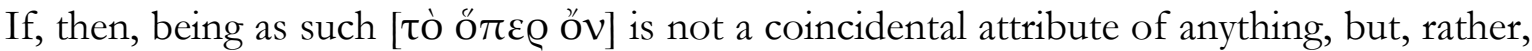
$<$ the other attributes $>$ are coincidental attributes of being, in what manner does "being as such" signify being, rather than a lack of being?

[1.] Given that being as such would also be white, being-white is still not something that as such is-being cannot be an attribute of being-white, for nothing that is not being as such $i s$.

[2.] Thus: whiteness is not-not in the sense that it is not such-and-such, but in the sense that it is lacks being entirely.

[3.] Thus: being as such is something that is not, since it is true to say that something is white. This, however, was seen to signify something that is not.

Even whiteness, then, signifies something that as such is, and being has many meanings. $(186 \mathrm{~b} 4-12)^{38}$

Furthermore, Aristotle shows that equating the univocal sense of being with substantial being will not make being an undifferentiated unity in the Parmenidean sense: to be a substance is always to instantiate a determinate species or substantial form, such as that of the human being, which can be further analyzed and defined with the help of more comprehensive generic determinations, such as "biped" and "animal." Even the substantial being of entities can thus be differentiated (186b14-35).

Aristotle has now conclusively shown that the presupposition of the univocal meaning of being, whether it is construed as attributable or as substantial being, cannot be maintained, as absurd consequences will follow. At least two different senses of "to be," irreducible to any unifying basic meaning, must be distinguished.

\section{b) Absolute and Relative Being/Nonbeing Distinguished}

Aristotle is in basic agreement with Parmenides's other presupposition, namely, that being is and nonbeing is not. There is indeed no nonbeing in the absolute sense of a contradictory opposite of 
being. But, for Aristotle, this is rather trivial. He lays great weight on the importance of seeing that there can be meaningful nonbeing in the relative sense of the absence of some determination, of not being such-and-such.

It is evidently not true that if being has a single meaning and cannot at the same time signify the contradictory opposite [ $\dot{\alpha} \nu \tau \hat{\imath} \varphi \alpha \sigma \iota v]$, there will be nothing that lacks being. For there is nothing to stop nonbeing from being-not in the absolute [ $\alpha \tilde{\alpha} \lambda \tilde{\omega} \varsigma]$ sense [of

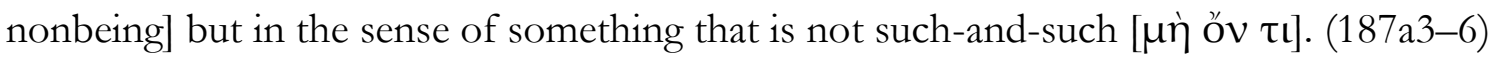

It is this distinction between absolute-indeterminate nonbeing and relative-determinate nonbeing-the latter understood as the contingent absence or privation ( $\sigma \tau \varepsilon \dot{\varrho} \emptyset \sigma \iota \varsigma)$ of a determinate attribute or substance-that allows Aristotle to finally do away with the Eleatic objections to the fundamental reality of becoming and change, and thus clear the intellectual obstacles to the philosophical science of physics. This is elaborated in Physics 1.7-8.

Change, for Aristotle, is always relative to an underlying substrate-a substantial entity for attributes, the basic matter for substantial entities - which itself persists while the absence of $x$ within it is transformed into the presence of $x$ : an unmusical human being turns into a musical human being, the matter contained in a seed grows into a tree (Physics 1.7.189b30-191a22). Numerically one and the same thing can have several determinations: one and the same individual can be both a human being and unmusical, one and the same human being can be both a doctor and a builder. Thus, while it may be correct to say that "the doctor builds houses," she does not do this in her capacity of a doctor, but insofar as she is also a builder; by analogy, the unmusical person does indeed become musical, but only insofar as a she is a person who is at first unmusical and then musical.

There are thus two senses in which $x$ can be said come to be from not- $x$ : (1) from something that is not $x$ insofar as it is not $x$, and (2) from something that is not $x$ insofar as it is something that, by coincidence ( $\kappa \alpha \tau \dot{\alpha} \sigma u \mu \beta \varepsilon \beta \eta \kappa o ́ s)$, is not $x$ but is equally capable of accommodating both $x$ and its absence. The first sense, that of the simple transition of a being from unqualified nonbeing to unqualified being, is what those who deny coming to be from 
nonbeing primarily have in mind, and Aristotle agrees that change is inconceivable in these terms. However, the second sense, the transition of a thing from the state of lacking an attribute to the state of possessing it, remains altogether plausible (Physics 1.8.191a33-b17). ${ }^{39}$ In a similar manner, $x$ can come to be from $x$, but only coincidentally: an animal can come to be from an animal and a dog from a dog, but only to the extent that an individual $A$, who is a $\operatorname{dog}$ and an animal, gives birth to individual B who is also a dog and an animal. What fundamentally happens here is that a material individual with certain determinations engenders new matter that becomes a numerically distinct individual with the same specific and generic determinations; animalhood does not come to be from animalhood or doghood from doghood (191b17-25).

\section{c) Aristotle's Presupposition: Being Itself as Being-something-determinate}

According to Aristotle's first analysis, the Parmenidean thesis that being is one and the same for all beings becomes implausible when one looks at the way in which being is attributed in declarative assertions: "being- $\chi$ " in the sense of being a determinate kind of substance and "being- $x$ " in the sense of possessing a determinate attribute are irreducible to a common denominator. According to the second analysis, while there is no absolute nonbeing pure and simple, there is relative not-being- $x$ in the sense of the absence or privation of determination $\chi$ from some substrate. From both of these analyses, it emerges that "being as such" has for Aristotle no other conceivable meaning than being-x-determinacy, being a determinate "something." This is made explicit in the question with which Aristotle concludes his discussion of Parmenides:

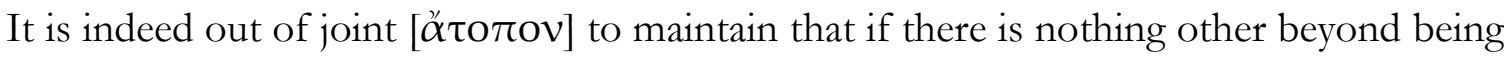

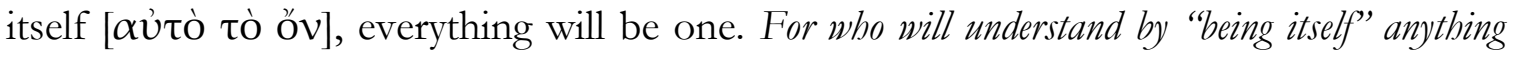

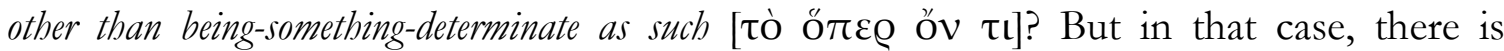
nothing to prevent beings from being a multiplicity, as we have said. It is thus obvious that being cannot possibly be one in this [Parmenidean] sense. (Physics 1.3.187a6-11; my italics) 
Aristotle's question whether "to be" has any other plausible meaning than "to be something determinate" should not be taken as a merely rhetorical one. It seems to signal an earnest perplexity as to whether Parmenides is indeed able to plausibly conceive "being itself' in some other sense. It shows the extent to which Aristotle has thought through Parmenides's thesis, as well as the fundamental difference between their intellectual frameworks. Most importantly, it shows the basic presupposition of Aristotle's entire critique: his approach to being in terms of its many specific instances, such as "to be a substance of the type $x, y$, or $z$, or an attribute F, G, or H of a substance." For Aristotle, the primary meaning of being is oú $\sigma$ í $\alpha$ in the sense of being a determinate and actualized entity that implements a specific "whatness." Secondary, dependent meanings of being include the different determinate attributes (qualities, quantities, relations) or modalities of such an entity. Because of this irreducibly equivocal character of determinate being, the unity of being cannot be a comprehensive unity in the Parmenidean sense. It must rather be conceived as a hierarchical unity, a unity of a common

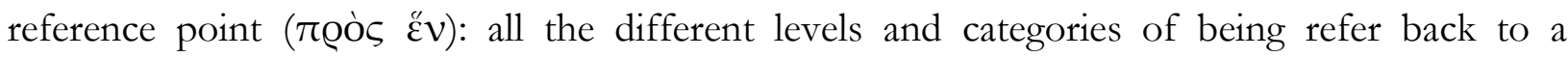
"standard" sense_-substantial entity-ness (oúoí $\alpha$ _-and, ultimately, to the most perfect substance/entity (Metaphysics 4.2.1003a33-b19; 7.1.1028a10-b7; 12.1.1069a18-b2).

\section{CONCLUSION: ThinkING BeING WiTHOUt BEINGS}

From a Heideggerian point of view, Aristotle's equation of being with being-somethingdeterminate thus belongs within the compass of the Platonic approach for which the most fundamental feature in beings is their ideal, definable whatness, the determinacy that grants them a degree of identity and permanence. Being is thought in terms of its discursive, linguistic

determinability. As the structural linguist Émile Benveniste points out, Aristotle's categorial ontology inherently presupposes that the structures of being correspond to those of language. ${ }^{40}$ In his Contributions to Philosophy, Heidegger summarizes this metaphysical approach in the following way: 


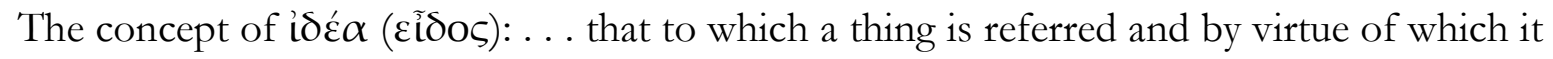
is the being that it is. . . The i $\delta^{\prime} \alpha$ : that to which what is still changing and is many is referred back, the unifying one. Therefore: öv, being [seiend] = unifying. As a consequence, the

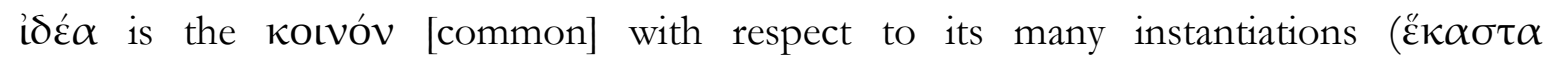
[particulars]). And, remarkably, this subsequent determination of the i $\delta \varepsilon \dot{\alpha} \alpha$ as beingness, as the kolvóv, then becomes the first and ultimate determination of beingness (or of being). And so being is the "most general"! Yet this is not strange; it is necessary, because from the very inception, being as beingness is experienced and thought only in terms of "beings" ..., only in terms of the many and with reference to the many. ${ }^{41}$

For Parmenides, by contrast, concepts and names are simply local delimitations and differentiations of the initial absolute unity of being/intelligibility. Parmenides's topic is precisely being in its prediscursive, undifferentiated unity, prior to its linguistic determination in discourse.

According to the later Heidegger's historical narrative, the contemporary philosophical situation is one in which the inherent implications of the Platonic-Aristotelian metaphysical tradition have completely unfolded and become conceptually articulated, particularly in the work of Hegel, Marx, and Nietzsche. ${ }^{42}$ This contemporary end or completion of metaphysics opens up entirely new possibilities for Western thinking. In his 1962 lecture "Time and Being," Heidegger characterizes his later project as an attempt "to think being without beings," which he elaborates as an attempt to think being "without regard to metaphysics"-without the metaphysical approach that seeks to "ground being in terms of beings," which has now become fully developed and exhausted. ${ }^{43}$ Heidegger's increasing interest in Parmenides stems from this project: in his final 1973 seminar, he maintains that the postmetaphysical experience of the clearing (Lichtung) of being is attainable only by way of a detour (Umweg), a return to the first inception (Rückekehr zum Anfang) — in particular, to Parmenides. However, the point is not to "go back to Parmenides," which as such would be unfeasible, but simply to turn towards (zuzukehren) Parmenides, to engage his thinking from out of our present position at the end of metaphysics. ${ }^{44}$ Parmenides is a thinker of pure and absolute accessibility, presence, and disclosure; when one emphasizes, with Heidegger, the finitude and situatedness of accessibility, 
the closure and concealment inherent in disclosure and unconcealment, the surrounding darkness presupposed by the "clearing," the $\lambda \eta \dot{\theta} \eta$ intrinsic to $\alpha \lambda \dot{\eta} \theta \varepsilon \iota \alpha$, one no longer thinks like Parmenides. ${ }^{45}$ The other, postmetaphysical inception of thinking is not identical with the first, protometaphysical one, but rather its reappropriative transformation. ${ }^{46}$

Nonetheless, according to the Heideggerian diagnosis of the contemporary intellectual juncture, it becomes possible in our specific situation to read Parmenides's Poem retrospectively as a "protometaphysical" attempt to "think being without beings" before the establishment of Platonic-Aristotelian metaphysics and its approach to being in terms of the beingness of beings-upon which, as we have now seen, Aristotle's critique of Parmenides hinges. Considered from this point of view, the character of Parmenides's thinking that Aristotle could not help regarding as a lack of adequate insight or of sufficient elaboration becomes imbued with an entirely new relevance and legitimacy, in an entirely new historical configuration.

\section{NOTES}

${ }^{1}$ I would like to thank an anonymous referee for a number of extremely helpful comments to an earlier version of this paper. For financial support, I am grateful to the Academy of Finland research project The Intellectual Heritage of Radical Cultural Conservatism. All translations from the Greek are my own.

2 Alfred North Whitehead, Process and Reality: An Essay in Cosmology [1929], 2nd ed., ed. David Ray Griffin and Donald W. Sherburne (New York: The Free Press, 1978), 39.

${ }^{3}$ Following established practice, I use "being" to translate Heidegger's Sein and Aristotle's tò öv and "beings" or "a being" to translate das Seiende/Seiendes and $\tau \dot{\alpha}$ ǒv $\alpha$.

${ }_{4}$ Plato, Phaedo, in Platonis opera, vol. 1, ed. John Burnet (Oxford: Clarendon Press, 1900); Republic, in Platonis opera, vol. 4, ed. John Burnet (Oxford: Clarendon Press, 1902).

${ }^{5}$ On the etymology and derivation of oủoía, see Pierre Chantraine, Dictionnaire étymologique de la langue grecque: bistoire des mots, vol. 2 (Paris: Klincksieck, 1970), 322.

${ }^{6}$ On this interpretation of oủoía, see, e.g., Martin Heidegger, Gesamtausgabe, vol. 18: Die Grundbegriffe der aristotelischen Philosophie [1924], ed. Mark Michalski (Frankfurt am Main: Klostermann, 2002), 21-35; Basic Concepts of Aristotelian Philosophy, trans. Robert D. Metcalf and Mark B. Tanzer (Bloomington: Indiana University Press, 2009), 17-26; Gesamtausgabe, vol. 31: Vom Wesen der menschlichen Freiheit: Einleitung in die 
Philosophie [1930], ed. Hartmut Tietjen, 2nd ed. (Frankfurt am Main: Klostermann, 1994), 40-73; The Essence of Human Freedom: An Introduction to Philosophy, trans. Ted Sadler (London: Continuum, 2002), 29-51. For an outstanding summary of this interpretation, see Thomas Sheehan, Making Sense of Heidegger: A Paradigm Shift (London: Rowman \& Littlefield, 2015), 33-6.

7 Aristotle, Categories, in Categoriae et liber de interpretatione, ed. Lorenzo Minio-Paluello (Oxford: Clarendon Press, 1949).

8 Martin Heidegger, Gesamtausgabe, vol. 65: Beiträge zur Philosophie (Vom Ereignis) [1936-38], ed. FriedrichWilhelm von Herrmann (Frankfurt am Main: Klostermann, 1989), 75 (hereafter, GA 65); Contributions to Philosophy (Of the Event), trans. Richard Rojcewicz and Daniela Vallega-Neu (Bloomington, IN: Indiana University Press, 2012), 60 (hereafter, CP).

${ }^{9}$ Heidegger, GA 65, 75-6; CP, 60-1; translation modified.

${ }_{10}$ Martin Heidegger, Nietzsche, vol. 2, 6th ed. (Stuttgart: Neske, 1998), 373 (hereafter, N II); The End of Philosophy, trans. Joan Stambaugh (Chicago: University of Chicago Press, 2003), 10 (hereafter, EP); translation modified. Cf. the discussion in N II, 363-73; EP, 1-10.

${ }^{11}$ See Martin Heidegger, Gesamtausgabe, vol. 66: Besinnung [1938-1939], ed. Friedrich-Wilhelm von Herrmann (Frankfurt am Main: Klostermann, 1997), 383 (hereafter, GA 66); Mindfulness, trans. Parvis Emad and Thomas Kalary (London: Continuum, 2006), 339 (hereafter, M). Cf. GA 65, 211; CP, 165.

12 Heidegger, GA 66, 382-5; M, 339-41.

13 According to Aristotle, this duality of binary opposites dominated the early philosophy of nature; Aristotle, Physics, ed. W. D. Ross (Oxford: Clarendon Press, 1936), 1.5.188a19-30.

14 Aristotle's discussions of Parmenides and the Eleatics can be found in Metaphysics 1.5 and in De caelo 3.1, and in De generatione et corruptione 1.8, and more extensively in Physics 1.2-3, 8 and 6.9; see Aristotle, Metaphysics, 2 vols, ed. W. D. Ross (Oxford: Clarendon Press, 1924), 1.5.986b18-987a2; De caelo, ed. Paul Moraux (Paris: Les Belles Lettres, 1965), 3.1.298b14-23; De generatione et corruptione, ed. Charles Mugler (Paris: Les Belles Lettres, 1966), 1.8.325a2-23; Physics 1.2.184b15-3.187a11, 1.8.191a24-b34, 6.9.239b5-240b7. Aristotle also briefly discusses Melissus in the Sophistical Refutations, in Topica et sophistici elenchi, ed. W. D. Ross (Oxford: Clarendon Press, 1958), 5.167b13-20, 6.168b35-169a5. An extensive discussion of Melissus can be found in the short doxographical treatise De Melisso Xenophane Gorgia, traditionally included in the Aristotelian corpus but now considered a spurious work by a much later author; Hermann Diels, "Aristotelis qui fertur de Melisso Xenophane Gorgia libellus," in Abhandlungen der königlichen Akademie der Wissenschaften zu Berlin, Philosophisch-historische Klasse (Berlin: Reimer, 1900), 15-35.

15 Heidegger's comments on the critique of Eleatic philosophy in Physics 1 can be found in his 1922 lecture course and a related manuscript; Martin Heidegger, Gesamtausgabe, vol. 62: Pbänomenologische Interpretationen 
ausgewählter Abhandlungen des Aristoteles zur Ontologie und Logik [1922], ed. Günther Neumann (Frankfurt am Main: Klostermann, 2005), 165-339, 392-5 (hereafter, GA 62); Supplements: From the Earliest Essays to Being and Time and Beyond, trans. John van Buren et al., ed. John van Buren (Albany: State University of New York Press, 2002), 140-2.

${ }^{16}$ See Walter Brogan, Heidegger and Aristotle: The Twofoldness of Being (Albany: State University of New York Press, 2005), xi, 18, 112-3, 126-7; Jussi Backman, "Divine and Mortal Motivation: On the Movement of Life in Aristotle and Heidegger," Continental Philosophy Review 38 (2005): 241-61; Sean D. Kirkland, "On AntiParmenidean Temporality in Aristotle's Physics," Epoché 12 (2007): 49-62; Sheehan, Making Sense of Heidegger, 45-53, 65.

17 On the fundamentally anti- or trans-Aristotelian aims of Heidegger's project, see Werner Marx, Heidegger and the Tradition [1961], trans. Theodore Kisiel and Murray Greene (Evanston, Ill.: Northwestern University Press, 1971); Ted Sadler, Heidegger and Aristotle: The Question of Being (London: Athlone, 1996); Catriona Hanley, Being and God in Aristotle and Heidegger: The Role of Method in Thinking the Infinite (Lanham, Md.: Rowman \& Littlefield, 2000); Sheehan, Making Sense of Heidegger, 67-107; Jussi Backman, Complicated Presence: Heidegger and the Postmetaphysical Unity of Being (Albany: State University of New York Press, 2015), 19-68.

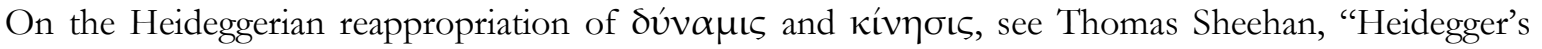
Interpretation of Aristotle: Dynamis and Ereignis", Philosophy Research Archives 4 (1978): 278-314; "Heidegger's Topic: Excess, Recess, Access," Tijdschrift voor Filosofie 41 (1979): 615-35; “On Movement and the Destruction of Ontology," The Monist 64 (1981): 534-42; “On the Way to Ereignis: Heidegger's Interpretation of Physis," in Continental Pbilosopby in America, ed. Hugh J. Silverman, John Sallis, and Thomas M. Seebohm (Pittsburgh: Duquesne University Press, 1983), 131-64; Franco Volpi, "La 'riabilitazione' della dynamis e dell'energeia in Heidegger," Aquinas 33 (1990): 3-27; Hans-Georg Gadamer, Gesammelte Werke, vol. 10: Hermeneutik im Rückblick (Tübingen: Mohr, 1995), 43-5; Walter Brogan, "Heidegger's Interpretation of Aristotle on the Privative Character of Force and the Twofoldness of Being," in Interrogating the Tradition: Hermeneutics and the History of Philosophy, ed. Charles E. Scott and John Sallis (Albany: State University of New York Press, 2000), 111-30; Brogan, Heidegger and Aristotle; Catriona Hanley, "Force and Dynamism in Aristotle and Heidegger: Becoming What You Are... To Be," in Life: Energies, Forces and the Shaping of Life: Vital, Existential, ed. AnnaTeresa Tymieniecka (Dordrecht: Kluwer, 2002), 3-18; Charlotta Weigelt, The Logic of Life: Heidegger's Retrieval of Aristotle's Concept of Logos (Stockholm: Almqvist \& Wiksell, 2002), 134-9, 190-223; Backman, "Divine and Mortal Motivation"; Francisco J. Gonzalez, "Whose Metaphysics of Presence? Heidegger's Interpretation of Energeia and Dunamis in Aristotle," The Southerm Journal of Philosophy 44 (2006): 533-68; Servanne Jollivet, "Das Phänomen der Bewegtheit im Licht der Dekonstruktion der aristotelischen Physik," in Heidegger-Jabrbuch, vol. 3: Heidegger und Aristoteles, ed. Alfred Denker et al. (Freiburg: Alber, 2007), 130-55. 


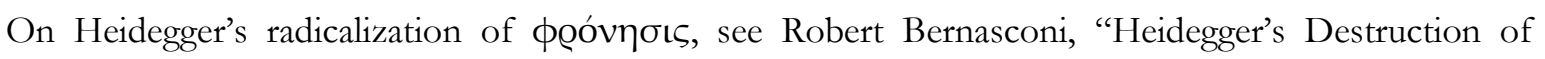
Phronesis,” The Southern Journal of Philosophy, 28 (1990): 127-47; Franco Volpi, “'Sein und Zeit': Homologien zur 'Nikomachischen Ethik," Philosophisches Jabrbuch 96 (1989): 225-40; "Dasein as Praxis: The Heideggerian Assimilation and the Radicalization of the Practical Philosophy of Aristotle," trans. Christopher Macann, in Martin Heidegger: Critical Assessments, vol. 2: History of Philosophy, ed. Christopher Macann (London: Routledge, 1992), 90-129; Jacques Taminiaux, Heidegger and the Project of Fundamental Ontology, trans. Michael Gendre (Albany: State University of New York Press, 1991), 111-37; John van Buren, “The Young Heidegger, Aristotle, Ethics," in Ethics and Danger: Essays on Heidegger and Continental Thought, ed. Arleen B. Dallery, Charles E. Scott, and P. Holley Roberts (Albany, NY: State University of New York Press, 1992), 169-85; William McNeill, The Glance of the Eye: Heidegger, Aristotle, and the Ends of Theory (Albany: State University of New York Press, 1999), 15-157; Christopher P. Long, "The Ontological Reappropriation of Phronèsis," Continental Philosophy Review 35 (2002): 35-60; Jussi Backman, "Für das Wohnen denken: Heidegger, Arendt, und die praktische Besinnung," in Heidegger-Jahrbuch, vol. 3, 199-220; Gregory Fried, "Retrieving phronêsis: Heidegger on the Essence of Politics," Continental Philosophy Review 47 (2014): 293-313.

${ }^{18}$ See, e.g., Christopher Long, The Ethics of Ontology: Rethinking an Aristotelian Legacy (Albany: State University of New York Press, 2004); Aristotle on the Nature of Truth (Cambridge: Cambridge University Press, 2011); Claudia Baracchi, Aristotle's Ethics as First Philosophy (Cambridge: Cambridge University Press, 2008); Sean Kirkland, "Dialectic and Proto-Phenomenology in Aristotle's Topics and Physics," Proceedings of the Boston Area Colloquium in Ancient Philosopby 29 (2014): 185-213; "On the Ontological Primacy of Relationality in Aristotle's Politics and the 'Birth' of the Political Animal," Epoché 21 (2017): 401-20.

${ }_{19}$ DK = Hermann Diels and Walther Kranz, Die Fragmente der Vorsokratiker: Griechisch und Deutsch [1903], 6th ed. (Berlin: Weidmannsche Buchhandlung, 1951). On this reading of the opening of the Poem, see Mitchell Miller, "Parmenides and the Disclosure of Being," Apeiron 13 (1979): 12-35.

${ }^{20}$ On the interpretation of $\dot{\alpha} \lambda \eta \dot{\theta \varepsilon \iota \alpha}$ as “evidence," see Ernst Heitsch, Parmenides: Die Fragmente: Griechisch und deutsch, 3rd ed. (Zurich: Artemis \& Winkler, 1995), 90-8.

${ }^{21}$ On the $\delta o ́ \xi \alpha \mathrm{l}$ as "acceptances"— $-\delta o ́ \xi \alpha$ is a cognate of $\delta \varepsilon \dot{\chi} \chi \mathrm{O} \mu \alpha \mathrm{l}$, "to receive, to accept" and ultimately derives from the Proto-Indo-European base *dek-, "to take, to accept"- see Alexander P. D. Mourelatos, The Route of Parmenides: A Study of Word, Image, and Argument in the Fragments (New Haven, Conn.: Yale University Press, 1970), 194-221. On the etymology of $\delta o ́ \xi \alpha$, see Pierre Chantraine, Dictionnaire étymologique de la langue grecque: histoire des mots, vol. 1 (Paris: Klincksieck, 1968), 290-1.

22 See Karl Reinhardt, Parmenides und die Geschichte der griechischen Pbilosophie (Bonn: Cohen, 1916); cf. Hans Schwabl, "Sein und Doxa bei Parmenides," Wiener Studien 66 (1953): 50-75. For Heidegger's laudatory comments on Reinhardt's work, see Martin Heidegger, Sein und Zeit [1927], 18th ed. (Tübingen: Niemeyer, 
2001), 223n1; Being and Time, trans. Joan Stambaugh, rev. Dennis Schmidt (Albany: State University of New York Press, 2010), 214n39.

${ }^{23}$ In 1.32, Diels and Kranz have $\pi \alpha ́ v \tau \alpha \pi \varepsilon \varrho \tilde{\omega} v \tau \alpha$, which is found in only one out of four manuscripts; this would alter the sense of the passage to say that the $\delta$ ó $\xi \alpha \iota$ "thoroughly pervade all things." For defenses of

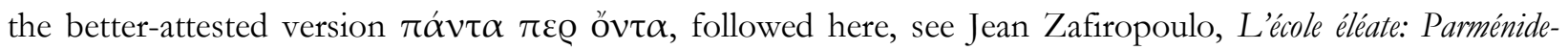
Zénon-Mélissos (Paris: Les Belles Lettres, 1950), 295-7; G. E. L. Owen, “Eleatic Questions,” Classical Quarterly 10 (1960): 84-9; Mourelatos, The Route of Parmenides, 212-6; Rémi Brague, "La vraisemblance du faux (Parménide, fr. I, 31-32)," in Études sur Parménide, vol. 2: Problèmes d'interprétation, ed. Pierre Aubenque (Paris: Vrin, 1987), 44-68.

${ }^{24}$ For similar readings of B 4, see Barrington Jones, "Parmenides' 'The Way of Truth'," Journal of the History of Philosophy 11 (1973): 293-4; Tomás Calvo, “Truth and Doxa in Parmenides," Archiv für Geschicbte der Philosophie 59 (1977): 250. Cf. Jussi Backman, “Towards a Genealogy of the Metaphysics of Sight: Seeing, Hearing, and Thinking in Heraclitus and Parmenides," in Phenomenology and the Metaphysics of Sight, ed. Antonio Cimino and Pavlos Kontos (Leiden: Brill, 2015), 11-34.

${ }_{25}$ This is emphasized by Heidegger, who contrasts B 3 with Berkeley's dictum esse est percipi; Martin Heidegger, Vorträge und Aufsätže, 9th ed. (Stuttgart: Neske, 2000), 226-9 (hereafter, VA); Early Greek Thinking, trans. David Farrell Krell and Frank A. Capuzzi (New York: Harper \& Row, 1984), 82-4.

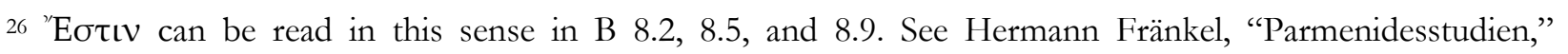
Nachrichten von der Gesellschaft der Wissenschaften zu Göttingen: Philologisch-Historische Klasse (1930): 118n3; Leonardo Tarán, Parmenides: A Text with Translation, Commentary, and Critical Essays (Princeton, N.J.: Princeton University Press, 1965), 33-7.

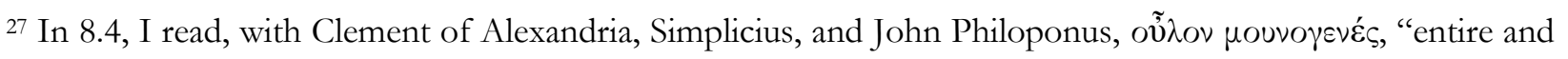

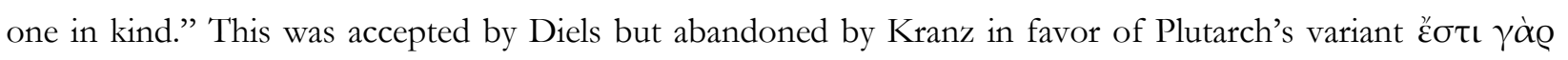

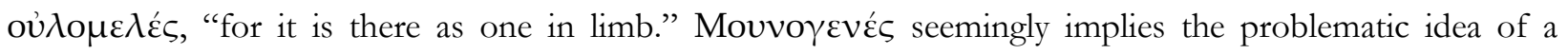
"genesis" of being; however, it can be read as simply meaning "one in kind, homogeneous." See Mourelatos, The Route of Parmenides, 113-4; Lambros Couloubaritsis, Mythe et philosophie chez Parménide (Brussels: Ousia, 1986), 222-5.

${ }^{28}$ Charles H. Kahn, “The Greek Verb 'To Be' and the Concept of Being,” Foundations of Language 2 (1966): $254-5$.

${ }^{29}$ Cf. Martin Heidegger, Gesamtausgabe, vol. 22: Die Grundbegriffe der antiken Philosophie [1926], ed. Franz-Karl Blust (Frankfurt am Main: Klostermann, 1993), 67-9; The Basic Concepts of Ancient Philosophy, trans. Richard Rojcewicz (Bloomington, IN: Indiana University Press, 2008), 56-7; Jones, "Parmenides' 'The Way of 
Truth," 294-5; Jonathan Barnes, The Presocratic Philosophers, vol. 1: Thales to Zeno (London: Routledge \& Kegan Paul, 1979), 194.

${ }^{30}$ I follow here Leonard Woodbury's reading of 8.38; Leonard Woodbury, "Parmenides on Names," Harvard Studies in Classical Pbilology 63 (1958): 147-9.

31 See Martin Heidegger, Holzwege, 8th ed. (Frankfurt am Main: Klostermann, 2003), 344-5; Off the Beaten Track, trans. Julian Young and Kenneth Haynes (Cambridge: Cambridge University Press, 2002), 259-60; Was heisst Denken? [1951-52], 5th ed. (Tübingen: Niemeyer, 1997), 130-8, 174-5; What Is Called Thinking? trans. J.

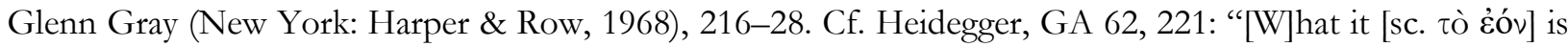
is the 'it is' [das 'es ist'] and uniquely that" (my translation).

${ }^{32}$ Charles H. Kahn, The Verb "Be" and its Synonyms: Philosophical and Grammatical Studies, vol. 6: The Verb "Be" in Ancient Greek (Dordrecht: Reidel, 1973), 373-9.

${ }_{33}$ Michael J. Loux notes that $\tilde{T}$. there in advance"; Michael J. Loux, "Aristotle and Parmenides: An Interpretation of Physics A.8," Proceedings of the Boston Area Colloquium in Ancient Philosophy 8 (1992): 284.

${ }^{34}$ Simplicius, following Alexander of Aphrodisias, thinks that púoıs must here be taken as referring to the

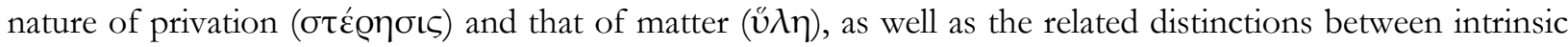
and contingent absence and between act and potency that Aristotle has just been discussing; Simplicius, Commentaria in Aristotelem Graeca, vol. 9: Simplicii in Aristotelis physicorum libros octo commentaria, vol. 1, ed. Hermann Diels (Berlin: Reimer, 1882), 242.4-13. This reading is followed by most ancient and medieval commentators; cf. John Philoponus, Commentaria in Aristotelem Graeca, vol. 16: Ioannis Philoponi in Aristotelis physicorum libros octo commentaria, vol. 1, ed. Girolamo Vitelli (Berlin: Reimer, 1887), 182.2-10; St. Thomas Aquinas, In octo libros Physicorum expositio, in Sancti Thomae Aquinatis opera omnia, vol. 2: Commentaria in octo libros Physicorum Aristotelis (Rome: Vatican Polyglot Press, 1884), lib. 1, c. 8, lect. 14.9. W. D. Ross thinks that

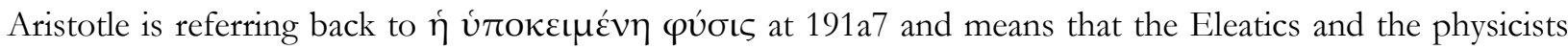
did not see $\varphi v ́ \sigma ı \varsigma$ in the specific sense of the substratum, of the materiality and relative absence of form that underlies the instantiation of any form; W. D. Ross, Aristotle's Physics, 497; cf. Harold Cherniss, Aristotle's Criticism of Presocratic Philosophy (New York: Octagon Books, 1964), 172n124; Leonardo Tarán, "Monism and Presocratic Philosophy," in Monism, ed. Andreas Bächli and Klaus Petrus (Frankfurt: ontos verlag, 2003), $17 \mathrm{n} 43$.

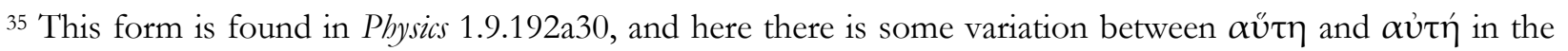
manuscripts. Even if the standard reading is maintained, $\varphi v ́ \sigma \iota \varsigma$ in $191 \mathrm{~b} 34$ can be taken as referring to the

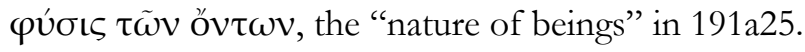


${ }^{36}$ See W. D. Ross' commentary, Aristotle's Physics, 473.

${ }^{37}$ Cf. Immanuel Kant, Kritik der reinen Vernunft, ed. Jens Timmermann (Hamburg: Meiner, 1998), 673 (A 598, B 626); Critique of Pure Reason, trans. Paul Guyer and Allen W. Wood (Cambridge: Cambridge University Press, 1998), 567.

38 "The other attributes" in $186 \mathrm{~b} 5$ is a conjectural insertion by W. D. Ross.

${ }^{39}$ For a detailed discussion of this solution of the Eleatic dilemma and of the problematic character of the expression $\kappa \alpha \tau \grave{\alpha} \sigma u \mu \beta \varepsilon \beta \eta \kappa o ́ \varsigma$ in this context, see Loux, "Aristotle and Parmenides."

40 Émile Benveniste, Problèmes de linguistique générale (Paris: Gallimard, 1966), 63-74; Problems in General Linguistics, trans. Mary Elizabeth Meek (Coral Gables, FL: University of Miami Press, 1971), 55-64.

${ }^{41}$ Heidegger, GA 65, 208-9; CP, 163-4; translation modified.

42 See Martin Heidegger, VA, 67-95; EP, 84-110; N II, 177-80; Nietssche, vol. 4: Nibilism, trans. Frank A. Capuzzi, ed. David Farrell Krell (San Francisco: HarperSanFrancisco, 1991), 147-9; Zur Sache des Denkens, 4th ed. (Tübingen: Niemeyer, 2000), 61-5 (hereafter, ZSD); On Time and Being, trans. Joan Stambaugh (New York: Harper \& Row, 1972), 55-9 (hereafter, OTB).

${ }^{43}$ Martin Heidegger, ZSD, 25, 35-6; OTB, 24, 33.

44 Martin Heidegger, Gesamtausgabe, vol. 15: Seminare, ed. Curd Ochwadt, 2nd ed. (Frankfurt am Main: Klostermann, 2005), 394 (hereafter, GA 15); Four Seminars, trans. Andrew Mitchell and François Raffoul (Bloomington, IN: Indiana University Press, 2003), 77 (hereafter, FS).

${ }^{45}$ Heidegger, GA 15, 395; FS, 78. Heidegger here corrects his earlier "overinterpretation" of Parmenides; cf. ZSD, 78-9; OTB, 71.

46 See, e.g., Heidegger, GA 65, 185-6; CP, 145-6. Cf. Heidegger's letter to Gadamer, December 2, 1971: "This experiencing of 'aletheia' [sc. as such] is the step back to the 'most ancient of what is ancient' ..., the entry [Einkehr] into the 'other inception,' in other words into the one and the selfsame unique inception of Western-European thinking, but this inception thought in another manner." Hans-Georg Gadamer, Gesammelte Werke, vol. 4: Neuere Philosophie, vol. 2: Probleme, Gestalten (Tübingen: Mohr, 1987), 482n31; The Gadamer Reader: A Bouquet of the Later Writings, trans. Richard E. Palmer et al., ed. Richard E. Palmer (Evanston, Ill.: Northwestern University Press, 2007), 458n33; translation modified. 